\title{
Maastricht University graduate surveys 2011
}

Citation for published version (APA):

Meng, C. M., Humburg, M., \& Huijgen, T. G. (2011). Maastricht University graduate surveys 2011. ROA. ROA Fact Sheets No. 004 https://doi.org/10.26481/umarof.2011004

Document status and date:

Published: 01/01/2011

DOI:

10.26481/umarof.2011004

Document Version:

Publisher's PDF, also known as Version of record

\section{Please check the document version of this publication:}

- A submitted manuscript is the version of the article upon submission and before peer-review. There can be important differences between the submitted version and the official published version of record.

People interested in the research are advised to contact the author for the final version of the publication, or visit the DOI to the publisher's website.

- The final author version and the galley proof are versions of the publication after peer review.

- The final published version features the final layout of the paper including the volume, issue and page numbers.

Link to publication

\footnotetext{
General rights rights.

- You may freely distribute the URL identifying the publication in the public portal. please follow below link for the End User Agreement:

www.umlib.nl/taverne-license

Take down policy

If you believe that this document breaches copyright please contact us at:

repository@maastrichtuniversity.nl

providing details and we will investigate your claim.
}

Copyright and moral rights for the publications made accessible in the public portal are retained by the authors and/or other copyright owners and it is a condition of accessing publications that users recognise and abide by the legal requirements associated with these

- Users may download and print one copy of any publication from the public portal for the purpose of private study or research.

- You may not further distribute the material or use it for any profit-making activity or commercial gain

If the publication is distributed under the terms of Article $25 \mathrm{fa}$ of the Dutch Copyright Act, indicated by the "Taverne" license above, 


\section{Maastricht University graduate surveys 2011}

\section{ROA Fact Sheet}

ROA-F-2011/4

Researchcentrum voor Onderwijs en Arbeidsmarkt | ROA Research Centre for Education and the Labour Market | ROA 


\section{Maastricht University graduate surveys 2011}

How successful is Maastricht University in providing its students with the knowledge and skills necessary to succeed in the labour market? What career paths are Maastricht University Alumni taking in the short and medium term, and how do they look back on their time in Maastricht? This fact sheet presents the most important results of a survey among two cohorts of Maastricht University alumni. One cohort graduated in the academic year 2004-2005 (6.5 years prior to the survey), the other cohort graduated in the academic year 1999-2000 ${ }^{\mathrm{I}}$ (II.5 years prior to the survey).

\section{Position in the labour market}

Table I gives a detailed overview of graduates' employment status by cohort and faculty. On average, 93\% of alumni of the 2004-2005 cohort and 95\% of alumni of the 19992000 cohort have paid work. Of those alumni active in the labour market, 4\% (2004-2005 cohort) and 2\% (1999-2000 cohort) are unemployed. Keeping in mind that a substantial part of this unemployment rate is frictional (i.e. the time period between two jobs), involuntary unemployment does not seem to be a problem amongst Maastricht University graduates, possibly with the exception of Psychology and Neuroscience graduates some five years after graduation.

Considering the above figures, labour market participation is very high for both cohorts of Maastricht University graduates. As a matter of fact, all disciplines taken together, only $2 \%$ of graduates of 2004-2005 and $3 \%$ of graduates of $1999-2000$ report to be out of the labour force, with the only significant outlier being Medical graduates ( $8 \%$ of the $2004-2005$ cohort inactive). When asked for the reason of their inactivity, a majority reports to be participating in further education or to be taking care of children or relatives.

Table 1

Paid work and unemployment

\begin{tabular}{lcccc}
\hline & \multicolumn{2}{c}{ \% paid work } & \multicolumn{2}{c}{ \% unemployed } \\
& $2004-2005$ & $1999-2000$ & $2004-2005$ & $1999-2000$ \\
\hline Humanities and Sciences & $\mathrm{x}$ & $\mathrm{x}$ & $\mathrm{x}$ & $\mathrm{x}$ \\
Business and Economics & 94 & 95 & 5 & 3 \\
Health and Life Sciences & 94 & 96 & 3 & 2 \\
Medicine & 90 & 95 & 2 & 3 \\
Arts and Social Sciences & 93 & $\mathrm{x}$ & 4 & $\mathrm{x}$ \\
Psychology and Neuroscience & 90 & 96 & 10 & 0 \\
Law & 95 & 97 & 4 & 0 \\
Maastricht University & 93 & 95 & 4 & 2 \\
\hline
\end{tabular}

$\mathrm{x}=$ too few cases

I. $35 \%$ of the $18 \mathrm{I} 6$ graduates from the $2004-2005$ cohort and $36 \%$ of the I2O2 graduates from $1999-2000$ took part in the survey.
Most of the alumni change jobs at least once during the first five years in the labour market. Only II\% of graduates of the 2004-2005 cohort and 3.8\% of graduates of the 1999-2000 cohort are still employed in their first job. As can be seen in Figure I, the 2004-2005 cohort of Maastricht University graduates have on average held three jobs until $201 \mathrm{I}$. Graduates of the 1999-2000 cohort have on average held four jobs. Most job changes are associated with a change of employers. Although these figures stem from two different cohorts and can therefore not be compared in a strict sense, they indicate that most job mobility takes place in the first years of the transition into the labour market. This is especially true for professional careers associated with a law degree, while for example Business and Economics graduates still display a fair amount of job mobility in the second five years in the labour market.

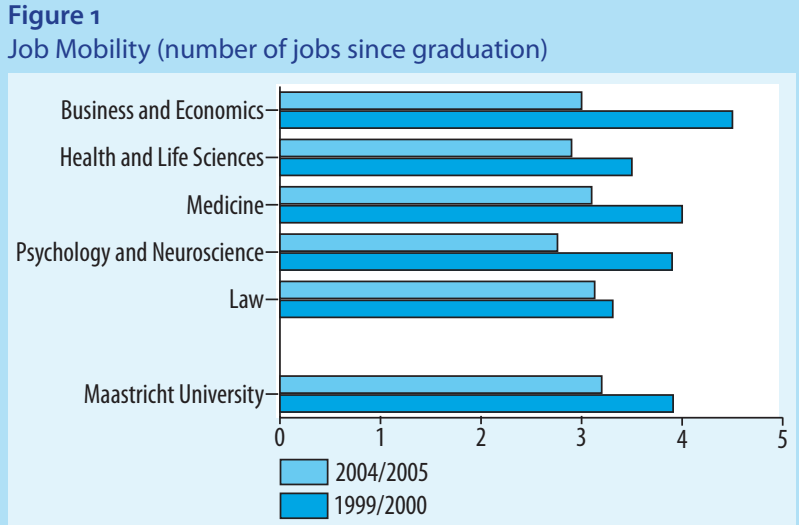

\section{Job characteristics}

The match between graduates' education and the requirements of their job has important implications for the extent to which graduates can use their knowledge and skills. The quality of the education-job match is therefore positively related to job satisfaction, career opportunities and wages. Table $2 \mathrm{a}$ presents the proportion of Maastricht University graduates with a good horizontal education-job match, that is, the percentage of alumni who work in jobs for which their own or a related field of study is required. The results are positive, with $85 \%$ of alumni working in a good horizontal match. By nature of their very specific education, all Medial graduates are well matched. In contrast, $24 \%$ of the 2004-2005 graduates from Arts and Social Sciences currently have a job unrelated to their field of study. The quality of their horizontal match is therefore below Maastricht University average. However, while one third of these mismatched graduates say that they were not able to find a job related to their field of study, almost half report that a change in interest was the reason for working outside their field. 
In addition to the horizontal match, the vertical match (i.e. whether graduates are working in a job for which a university degree is required) is an important indicator of the quality of the education-job match. Table $2 b$ shows that $84 \%$ of the respondents who graduated in 2004-2005 and $87 \%$ of the respondents who graduated in $1999-2000$ had an excellent vertical match between education and work at the time of the survey. There is, however, substantial variation between disciplines. All Medical graduates are perfectly matched. Psychology and Neuroscience, as well as Law graduates experience excellent vertical matching rates of above $90 \%$. By contrast, one out of four graduates from 2004-2005 with a Health and Life Science degree currently works below his or her educational level. These outcomes are highly correlated with degree specificity as well as labour market conditions in the particular field. In all disciplines and for both cohorts, the percentage of graduates with an excellent vertical match increased remarkably between the first and the current job.

Table $2 a$

Horizontal match

\begin{tabular}{|c|c|c|}
\hline & \multicolumn{2}{|c|}{$\begin{array}{l}\% \text { working in own or related } \\
\text { field of study }\end{array}$} \\
\hline & 2004-2005 & $1999-2000$ \\
\hline Humanities and Sciences & $x$ & $x$ \\
\hline Business and Economics & 82 & 89 \\
\hline Health and Life Sciences & 83 & 94 \\
\hline Medicine & 99 & 100 \\
\hline Arts and Social Sciences & 76 & $x$ \\
\hline Psychology and Neuroscience & 86 & 71 \\
\hline Law & 80 & 86 \\
\hline Maastricht University & 85 & 85 \\
\hline
\end{tabular}

Table $\mathbf{2 b}$

Vertical match

\begin{tabular}{lcccc}
\hline & $\begin{array}{c}\text { \% working at university } \\
\text { level or higher } \\
\text { first job }\end{array}$ & \multicolumn{2}{c}{$\begin{array}{c}\text { \%orking at university } \\
\text { level or higher } \\
\text { current job }\end{array}$} \\
& $2004-2005$ & $1999-2000$ & $2004-2005$ & $1999-2000$ \\
\hline Humanities and Sciences & $\mathrm{x}$ & $\mathrm{x}$ & $\mathrm{x}$ & $\mathrm{x}$ \\
Business and Economics & 76 & 85 & 82 & 89 \\
Health and Life Sciences & 58 & 62 & 76 & 80 \\
Medicine & 100 & 100 & 100 & 100 \\
Arts and Social Sciences & 77 & $\mathrm{x}$ & 84 & x \\
Psychology and Neuroscience & 76 & 83 & 91 & 95 \\
Law & 83 & 82 & 90 & 93 \\
Maastricht University & 75 & 77 & 84 & 87 \\
\hline
\end{tabular}

$x=$ too few cases

At the time of the survey, the median gross income of Maastricht University alumni of 2004-2005 is $€ 3500$ per month, and this rises to $€ 4500$ for the cohort of $1999-2000$ alumni (see Table 3). These numbers match the results of last year's survey and also income patterns across disciplines seem to remain stable: Health and Life Sciences alumni, Arts and Social Sciences alumni and Psychology and Neuroscience alumni have the lowest median income. Even after taking account of the considerably lower number of working hours per week of Health and Life Sciences and Psychology and Neuroscience alumni (especially for the I999-2000 cohort) substantial differences in salaries remain. For Health and Life Sciences graduates these differences might partly be explained by the lower than average quality of the education-job match.

With a median gross income of $€ 4300$ per month Business and Economics alumni earn most among the 20042005 cohort. After five further years in the labour market, Medical alumni seem to take over the top position with a median gross income of $€ 6000$ per month. Due to the structure of their career paths, Medical alumni are also the group which displays the biggest income growth between five and ten years after graduation. Maastricht University graduates from the three top income disciplines (Medicine, Business and Economics and Law) report regular working hours per week between 38 and 40. It is worth mentioning that these figures present contractual working hours excluding overtime. Actual working hours can deviate from these figures.

Table 3

Income and working hours

\begin{tabular}{lcccc}
\hline & \multicolumn{2}{c}{$\begin{array}{c}\text { gross income } \\
\text { per month }\end{array}$} & \multicolumn{2}{c}{$\begin{array}{c}\text { regular working } \\
\text { hours per week }\end{array}$} \\
& $2004-2005$ & $1999-2000$ & $2004-2005$ & $1999-2000$ \\
\hline Humanities and Sciences & $\mathrm{x}$ & $\mathrm{x}$ & $\mathrm{x}$ & $\mathrm{x}$ \\
Business and Economics & 4300 & 5600 & 40.0 & 40.0 \\
Health and Life Sciences & 3150 & 3850 & 36.0 & 32.0 \\
Medicine & 3800 & 6000 & 38.0 & 38.0 \\
Arts and Social Sciences & 2900 & $\mathrm{x}$ & 40.0 & $\mathrm{x}$ \\
Psychology and Neuroscience & 3000 & 3500 & 38.0 & 32.0 \\
Law & 4000 & 5150 & 40.0 & 38.0 \\
Maastricht University & 3500 & 4500 & 40.0 & 36.0 \\
\hline X
\end{tabular}

$x=$ too few cases

* Median of the gross income based on the contractual working hours in the main job.

Job satisfaction of Maastricht University graduates is generally high with $76 \%$ of alumni satisfied with their job among the 2004-2005 cohort and $80 \%$ of alumni satisfied with their job among the 1999-2000 cohort. The job satisfaction pattern across disciplines somewhat resembles income patterns, but they are certainly not congruent. For example, whereas Law graduates belong to the high income group, their level of job satisfaction is comparable to that of Psychology and Neuroscience graduates who earn considerably less. The level of job satisfaction of Health and 
Life Sciences alumni of the 2004-2005 cohort is comparable to the Maastricht University average, yet it is the only group where job satisfaction does not increase when comparing it to the older cohort. Among the 1999-2000 cohort, Health and Life Sciences alumni report well below average job satisfaction. The most satisfied are Medical alumni, with a remarkable $9 \mathrm{I} \%(97 \%)$ of respondents reporting to be satisfied with their job.

Table 4

Job satisfaction, career opportunities

\begin{tabular}{lcccc}
\hline & \multicolumn{2}{c}{$\begin{array}{c}\text { \% satisfied } \\
\text { with job }\end{array}$} & \multicolumn{2}{c}{ job offers good } \\
& career opportunities \\
& $2004-2005$ & $1999-2000$ & $2004-2005$ & $1999-2000$ \\
\hline Humanities and Sciences & $\mathrm{x}$ & $\mathrm{x}$ & $\mathrm{x}$ & $\mathrm{x}$ \\
Business and Economics & 76 & 81 & 75 & 75 \\
Health and Life Sciences & 74 & 73 & 53 & 50 \\
Medicine & 91 & 97 & 80 & 63 \\
Arts and Social Sciences & 68 & $\mathrm{x}$ & 52 & $\mathrm{x}$ \\
Psychology and Neuroscience & 69 & 81 & 49 & 67 \\
Law & 70 & 82 & 71 & 52 \\
Maastricht University & 76 & 80 & 66 & 60 \\
\hline
\end{tabular}

$\mathrm{x}=$ too few cases

The majority of Maastricht University alumni (66\% of the $2004-2005$ cohort and $60 \%$ of the $1999-2000$ cohort) find that their current job offers good career opportunities. Opportunity differences across disciplines closely follow income differences across disciplines, especially when looking at the more recent graduates. Among the 20042005 cohort, Health and Life Sciences, Arts and Social Sciences as well as Psychology and Neuroscience graduates see least career opportunities, while Medical alumni see most. When comparing the more recent cohort to the older cohort, however, career opportunities of Medical and Law graduates register a substantial drop, while career opportunities of Business and Economics graduates seem to remain stable at a fairly high level and career opportunities of Psychology and Neuroscience alumni even increase.

\section{Skill requirements}

In order to get a picture of job requirements, Maastricht University alumni were given a list of skills and were asked to rate the extent to which these skills were required to do their current job appropriately. The skills most extensively required are analytical thinking (the ability to analyse and solve problems), the ability to communicate effectively, the ability to take responsibility and the ability to work productively in teams. These results match intuition about the nature of graduate jobs. Analytical thinking and the ability to communicate effectively were reported to be required to a high or very high extent by $95 \%$ and $94 \%$ of alumni of both cohorts respectively, with low variation across disciplines. $95 \%$ of Medical graduates report the ability to take responsibility to be highly required to do their jobs, which is six percent above the total average. $89 \%$ of all alumni report team work to be of high importance in their job. Team work seems most important in jobs related to Psychology and Neuroscience degrees as well as Business and Economics degrees (93\%) and least important - yet still highly important - in law professions (80\%). Besides these more general skills, the importance of specific skills is not at all negligible: $75 \%$ of graduates report that their job required them to master their own field to a high or very high extent. In contrast, less than half of graduates state that knowledge of other fields is highly important, suggesting that being an expert of one's own field is still highly rewarded.

Alumni were also asked whether they had to deal with cultural, legal or ethical issues at work. A quite substantial percentage of Arts and Social Sciences graduates (69\%), Medical graduates $(60 \%)$ and Business and Economics graduates $(56 \%)$ have to deal with cultural aspects to a high or very high extent at work. Moreover, a substantial number of graduate jobs are concerned with legal and ethical issues. This is particularly true of jobs related to medical and law degrees, yet to a considerable extent also of jobs related to the other disciplines. $8 \mathrm{I} \%$ of Medical as well as Law graduates versus $50 \%-60 \%$ of graduates from other disciplines report to have to deal with legal and ethical issues to a high or very high extent in their daily work life.

Table 5 reports the percentage of graduates who report that the respective skill is required to a high or very high extent in their job.

\section{International work experience}

The international orientation of Maastricht University and the fact that English is the main language of instruction in many study programmes, is attracting an increasing number of foreign students. Figure 2a shows the percentage of Maastricht University alumni of the 2004-2005 cohort who are currently working outside the Netherlands. For Maastricht University as a whole, $20 \%$ of the 2004-2005 alumni cohort are working in European countries other than the Netherlands, and $3 \%$ are working outside of Europe. These numbers include foreign students who returned to their home country after graduation.

International orientation is not restricted to language use, it also means that the curriculum taught and the instruction method used prepare students for jobs on the 
Table 5

$\%$ of graduates who report that their job requires skill to a high or very high extent

\begin{tabular}{|c|c|c|c|c|c|c|c|c|}
\hline & $\begin{array}{l}\text { Humanities } \\
\text { and Sciences }\end{array}$ & $\begin{array}{l}\text { Business } \\
\text { and } \\
\text { Economics }\end{array}$ & $\begin{array}{l}\text { Health } \\
\text { and life } \\
\text { Sciences }\end{array}$ & Medicine & $\begin{array}{c}\text { Arts and } \\
\text { Social } \\
\text { Sciences }\end{array}$ & $\begin{array}{l}\text { Psychology } \\
\text { and } \\
\text { Neuroscience }\end{array}$ & Law & $\begin{array}{l}\text { Maastricht } \\
\text { University }\end{array}$ \\
\hline Analytical thinking & $x$ & 94 & 95 & 95 & 86 & 98 & 97 & 95 \\
\hline Ability to communicate effectively & $\mathrm{x}$ & 97 & 93 & 98 & 89 & 91 & 91 & 94 \\
\hline Ability to take responsibility & $x$ & 90 & 87 & 95 & 86 & 87 & 89 & 89 \\
\hline Ability to work productively in teams & $x$ & 93 & 88 & 89 & 89 & 93 & 80 & 89 \\
\hline Mastery of own field & $x$ & 76 & 76 & 94 & 72 & 80 & 80 & 79 \\
\hline Mastery of other fields & $x$ & 58 & 37 & 38 & 47 & 46 & 46 & 46 \\
\hline Ability to deal with cultural aspects of work & $\mathrm{x}$ & 56 & 38 & 60 & 69 & 42 & 43 & 48 \\
\hline Ability to deal with legal and ethical aspects of work & $\mathrm{x}$ & 53 & 60 & 80 & 61 & 47 & 81 & 62 \\
\hline
\end{tabular}

international labour market. Asked to what extent the education received at Maastricht University prepared them for the international labour market, $48 \%$ of the 2004-2005 alumni cohort responded that they felt prepared to a high or very high extent. Figure $2 b$ illustrates the relationship between feeling prepared to work abroad and actually working abroad. According to this figure, the School of Business and Economics is the most internationally oriented, with $77 \%$ of $2004-2005$ graduates feeling prepared for the international labour market and $44 \%$ actually working outside the Netherlands. This is followed by the Faculty of Arts and Social Sciences where 50\% of alumni feel prepared for the international labour market and 33\% work abroad. Interestingly, a substantial proportion of graduates from study programmes that almost entirely cater to the Dutch labour market, such as Medicine and Health and Life Sciences, feel well prepared to work abroad, presumably because the content of their study is strongly internationally transferable.

\section{Figure 2a}

Percentage currently working abroad (cohort 2004-2005)

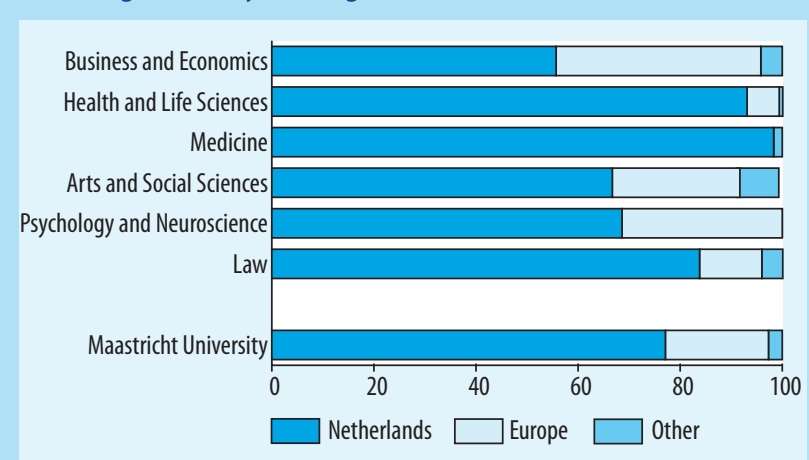

\section{Figure $\mathbf{2 b}$}

Percentage of alumni feeling well prepared for international labour market and percentage working abroad (cohort 2004-2005)

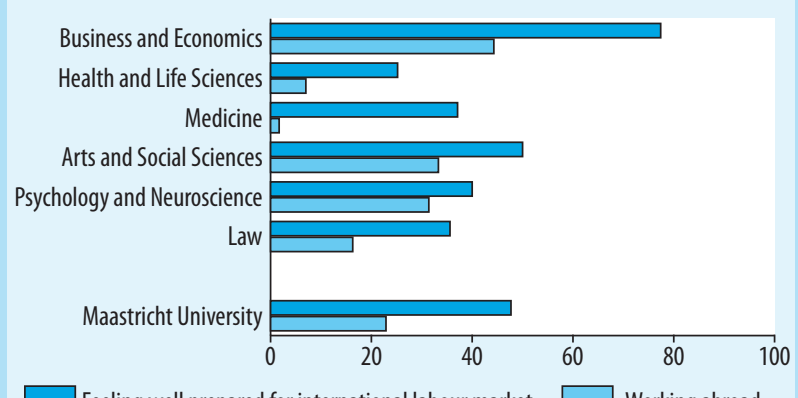

Feeling well prepared for international labour market $\square$ Working abroad

\section{Satisfaction with study at Maastricht University}

Finally, alumni were asked to look back on their time at Maastricht University and assess which choices they would make in retrospect. $88 \%$ and $85 \%$ of the alumni in respectively the 2004-2005 and 1999-2000 cohorts would again choose for Maastricht University. $75 \%$ and $72 \%$ respectively would choose the same study program and $13 \%$ of both cohorts would choose for a different study program but again at Maastricht University. Figure 3 presents the survey results for both cohorts by discipline.

\section{Figure 3}

Percentage of alumni who would again choose to study at Maastricht University

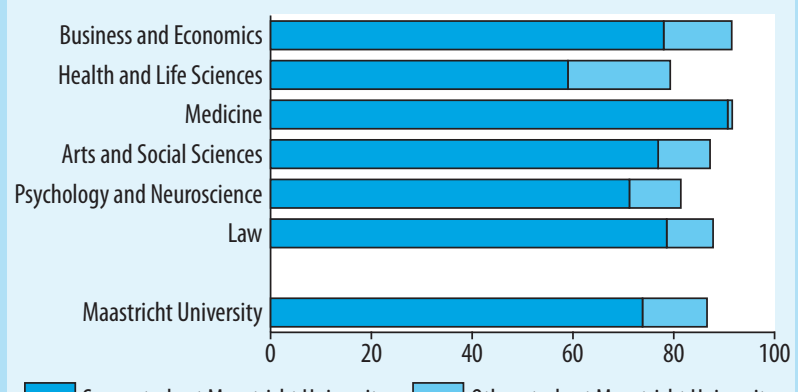

Same study at Maastricht University $\square$ 0ther study at Maastricht University 
In line with these findings, seven out of ten respondents think that their study at Maastricht University is still (very) useful for their current job. These results are very consistent across faculties and cohorts.

Even five and ten years after graduation, the bond between Maastricht University and its alumni is still strong. As part of the survey, alumni were asked whether Maastricht University could contact them to ask them to give a lecture or a presentation, to act as contact person in their company should internships become available there, or to act as a 'mentor' for current students. Almost $60 \%$ of the respondents indicated that they would like to become more involved in at least one of these Maastricht University alumni network and to thereby enable current students to learn and profit from the experiences of their older peers. 


\section{Colofon}

Copyright (C) 20II, Research Centre for Education and the Labour Market, Maastricht. No part of this publication may be reproduced in any way without prior permission of the Director of ROA.

Research Centre for Education and the Labour Market

P.O. Box 616

6200 MD Maastricht

The Netherlands

secretary-roa-sbe@maastrichtuniversity.nl

www.roa.nl

Maastricht University

School of Business and Economics

\section{Layout}

ROA secretary, Maastricht

December 20II 
Researchcentrum voor Onderwijs en Arbeidsmarkt

Postbus 616

6200 MD Maastricht

$\mathrm{T}+31433883647$

$\mathrm{F}+3143388491$

secretary-roa-sbe@maastrichtuniversity.n|

www.roa.nl

Maastricht University

School of Business and Economics 